Doc. PhDr. Jan Eichler, CSc.

Operace Sangaris 2013:

Vojenské rozhledy, 2014, roč. 23 (55), č. 2, s. 41-52, ISSN 1210-3292 (tištěná verze), ISSN 2336-2995 (on line).

\title{
Operation Sangaris 2013: French Intervention in Central Africa
}

\section{Abstrakt:}

Od loňského března zmitaji Středoafrickou republikou (SAR) násilnosti. Poté, co muslimšti bojovníci z hnutí Séléka odstranili křest’anského prezidenta Francoise Bozize, vypukl boj křestanských milic s muslimským obyvatelstvem. Prozatímní vláda muslima Michela Djotodii údajně záměrně vraždila civilisty, včetně žen, dětí a starcü. V prosinci 2013 byli z rozhodnutí Rady bezpečnosti OSN vysláni do země francouzští vojáci. Jejich kontingent o síle 1600 mužù měl pomoci vojski̊m Africké unie chránit civilní obyvatelstvo. Násili se však zatím nedaři zastavit. Počet lidi, kteři utíkaji z oblastí bojü, dosáhl téměr jednoho milionu. Zhruba 935 tisíc Středoafričanů se skrývá v buši či hledá pomoc u svých př́buzných. Z metropole Bangui uprchla až polovina obyvatel, 60 procent z nich tvoři děti, uvádí Úřad vysokého komisaře OSN pro uprchliky UNHCR.

\section{Abstract:}

The acts of violence have swept the whole Central African Republic (CAR) since March last year. When the Muslim fighters of Seleka rebel groups had deposed a Christian president Francois Bozize, the fighting between Christian militias and Muslim population broke out. The provisional government of the Muslim Michel Djotodia allegedly intentionally massacred civilians, including women, children and old people. In December 2013, under the resolution by the Security Council, UN, the French troops of 1600 men were sent to help to African Union soldiers to keep growing chaos at bay. But up to now, the violence has not been stopped. Nearly a million of people have been internally displaced in the country. A total of 935 thousand of Central Africans are currently sheltering in scrublands or living with their relatives. More than half of the city's population fled Bangui, some 60 per cent of those displaced are children, according to the UN refugee agency, UNHCR.

\section{Klíčová slova:}

Středoafrická republika (SAR), arentura OSN pro uprchlíky UNHCR, rezoluce Spojených národů, běženci (vyhnanci z domovů), mírová mise MISCA, operace Sangaris.

Key words:

Central African Republic (CAR), UN refugee agency UNHCR, United Nations resolution, internally displaced persons (IDP), peacekeeping mission MISCA, Sangaris Operation. 


\section{Úvod}

Dne 6. 12. 2013 byla zahájena další francouzská operace v Africe. Po operaci Serval v Mali, která i nadále probíhá, [1] se stala následující bojovou operací, kterou zahájil stávající prezident Francois Hollande, jinak v pořadí už sedmý prezident páté francouzské republiky. Zároveň s tím se jedná o třetí bojovou operaci, kterou Francie vede od počátku tohoto desetiletí. Tou první byl úder na Libyi v roce 2011, kdy funkci francouzského prezidenta zastával Nicolas Sarkozy. [2] Současná francouzská operace má svůj historický, náboženský, a také mezinárodněpolitický kontext. A má také, nebo spíše především svoji výraznou vojenskou charakteristiku, kterou tvoří nasazená technika, řešené úkoly, i zvolené postupy. A v neposlední řadě obsahuje některá významná poučení i pro Českou republiku a pro její armádu.

\section{Historický kontext}

Středoafrická republika (SAR) je zvláštní zemí, která se nachází na východo-západní ose Afriky, tedy v části, kterou v 19. století kolonizovala Francie. SAR je velká jako Francie či Ukrajina (622 984 km², tedy asi osminásobek ČR) a obývá ji zhruba pět milionů obyvatel. Patří mezi nejchudší na světě. Průměrný Středoafričan se dožije 51 let. Je první zemí na západ od osy severojižní (táhnoucí se od Egypta až po jižní Afriku), kterou zase kolonizovala Anglie. Na samém počátku 20. století se toto území oddělilo od tehdejšího Konga a bylo považováno za klíčový prostor pro případné další pronikání směrem k jižnímu Súdánu a později až do Džibuti, čím by se dokončilo budování východo-západní osy francouzského vlivu začínající na pobřeží Adenského zálivu Indického oceánu a končící v Dakaru, na pobřeží Atlantického oceánu. Francouzská geopolitická škola pro to má výraz „,bi-océanité“, [3] což se volně překládá jako kontrola území mezi dvěma oceány. $\mathrm{V}$ dějinách francouzské politiky vůči Africe se tedy SAR nachází na ose strategického významu, a tím je i vysvětleno, proč nemůže být v žádném prrípadě ponechána na pospas svému osudu.

SAR je jedním z několika málo afrických států bez př́istupu $\mathrm{k}$ moři. To předurčuje její uzavřenost, ale zároveň to i komplikuje úlohu př́ípadným vojenským intervencím. Dalším specifikem SAR je to, že její hlavní město Bangui se nachází nikoli v centru země, ale na samé její jižní hranici, která ji odděluje od Demokratické republiky Kongo (DRC). Z toho vyplývá, že jakákoliv krize v jedné zemi se pak zcela nezadržitelně odráží také v zemi sousední. V př́ípadě tohoto konkrétního konfliktu to znamená naléhavou hrozbu uprchlických vln ze SAR do DRC, což pak generuje zhoršení bezpečnosti v širším regionu střední Afriky.

Pokud jde o nejnovější dějiny SAR, ty jsou plné násilí. Od získání nezávislosti v r. 1960 se v zemi stř́idají diktátorské režimy, celkem osm převratů. Prvním prezidentem stal David Dacko, ale ten byl po pouhých pěti letech vlády svržen vojenským převratem, který vedl Jean-Bedel Bokassa. Tento usurpátor pak nastolil hrůzovládu, která trvala dlouhých 13 let, během nichž se stihl povýšit na maršála a prohlásit se za císaře. Jediné bohatství, které SAR má, jsou zásoby minerálů, diamantů, zlata a uranu. Zejména kvůli uranu, který byl v období studené války nesmírně žádaným artiklem, se o přízeň samovládce, jenž se v březnu 1972 prohlásil doživotním prezidentem, ucházela nejen 
Francie, ale například i USA a Švýcarsko. [4] Další vojenský převrat přišel v roce 1981, jeho vůdce generál André Kolingba byl u moci až do voleb uskutečněných na nátlak Francie v roce 1993.

Cestou vojenského převratu se k moci dostal i Francois Bozizé, a to v roce 2003, aby o dva roky později byl zvolen prezidentem, ale o dalších osm let později musel po útocích muslimské Séléky utéci do Kamerunu. A to už jsme u aktuální současnosti vyznačující se dalším násilím a krutostmi.

\section{Náboženský kontext}

Přibližně $50 \%$ obyvatelstva Středoafrické republiky se hlásí ke křest’anství, $35 \% \mathrm{k}$ místním africkým náboženstvím a $15 \% \mathrm{k}$ islámu.V březnu loňského roku v SAR vypukla už třetí etapa vleklé občanské války, když aliance muslimských sil nazvaná Séléka cestou vojenského převratu svrhla tehdejšího prezidenta, jímž byl již výše vzpomínaný křest’an Francois Bozizé a novým prezidentem země se prohlásil Michel Djotodia (odstoupil v lednu 2014). Znovu se tak začal naplňovat černý scénář amerického teoretika Samuela Huntingtona, který již před více než 20 lety varoval před hrozbou střetů na rozhraních mezi civilizačními okruhy. V případě SAR má tento střet vnitropolitický rozměr, což by v prrípadě dalšího vystupňování mohlo vést třeba i k rozbití státu. [5]

Ze strany muslimů sdružených v organizaci Séléka šlo do značné míry i o akt zoufalství, protože v samotné SAR byli stejně jako v sousedním Čadu či v Súdánu považováni za cizince, neměli žádné průkazy totožnosti. Pochod od severu směrem k metropoli se stal jejich specifickým způsobem boje o svá práva. Ale ani tak nelze nijak ospravedlnit, že přitom zabíjeli, ničili a plenili. Na řadě míst vyšli z kasáren, policistům a četníkům zabavovali jejich automobily a vyjížděli k honům na nemuslimské obyvatelstvo. Výsledkem tohoto běsnění byly liduprázdné ulice, zavřené tržnice i obchody. [6]

Situace v SAR byla o to horší, že začalo vzájemné vyvražd'ování, kterého se ostatně dopouštěly obě strany, jak muslimská Séléka, tak i křest’anské sebeobranné milice nazvané Antibalaka. [7] Nemuslimské obyvatelstvo hledalo útočiště v kostelích nebo v místech, kde byly francouzské jednotky, ale tato místa byla pro jejich nápor př́liš malá a nedostačující. Situace se dostala na samý práh genocidy. [8] Jen v samotném okolí letiště, které kontrovali francouzští vojáci, se shromáždilo 40000 křest’anských uprchlíků, kteří tam žili v doslova katastrofických podmínkách, bez jakékoliv pomoci, dokonce i bez toalet. Nastávaly až tak apokalyptické situace, že vyděšení rodiče museli rychle utéci, aniž by měli čas pohřbít své zabité děti. [9]

Na konec došlo k tomu, že plná polovina obyvatel SAR se v důsledku sílícího násilí dostala do situace vyžadující okamžitou humanitární pomoc, navíc počet vnitřně přesídlených lidí (IDP - Internally Displaced People) dosáhl počtu čtyř set tisíc, což byla celá jedna šestina veškerého obyvatelstva a počet lidí prchajících do sousedního Konga (DRC) se přiblížil ke stavu sto tisíc. Nastala tedy situace, která se vymykala jakékoliv kontrole. [10]

I když celý středoafrický konflikt měl jasné náboženské obrysy, měl i svoje specifické rysy. První z nich se projevil tím, že nejvyšší činitelé tří nejsilnějších církví od samého 
počátku odsuzovali násilí a vyzývali k míru. Projevilo se nebývalé souznění mezi protestantským pastorem, který vyzýval ke klidu „,svých“ $50 \%$ všeho obyvatelstva země, katolickým arcibiskupem, který k témuž nabádal „svých“ $30 \%$ a muslimským imámem, který se ve stejném duchu obracel na $15 \%$ obyvatelstva, jež se hlásí ke koránu. Stalo se dokonce i to, že arcibiskup poskytl úkryt imámovi, kterého chtěli lynčovat katolíci.

Středoafrická republika tak zažila nebývalou solidaritu a myšlenkovou spolupráci mezi nejvyššími činiteli tří hlavních církví v době, kdy mezi řadovými věřícími převládala oboustranná nenávist, jež dokonce přerůstala ve vzájemné vyvražd’ování a ničení posvátných církevních staveb. Proti nenávisti zdola, proti vzájemnému vyvražd'ování a ničení kostelů a mešit, se tak seshora postavily výzvy ke snášenlivosti a dokonce i ke vzájemnému odpuštění. [11] Velkou pozornost vyvolal společný článek, ve kterém naléhavě vyzvali k usmíření, ke vzájemnému odpuštění a k obnově násilnostmi postižené země. [12]

\section{Mezinárodněpolitický kontext}

Ale i napříč snaze nejvyšších náboženských činitelů vražedné šílenství v SAR nabývalo až genocidních rozměrů. Statisíce tamních katolíků začaly utíkat na jih, do DRC, a tak konflikt nabyl mezinárodních rozměrů. Francie jako bývalá koloniální velmoc musela jednat. Vedle snahy zastavit vyvražd'ovací běsnění se významným faktorem středoafrické krize stalo odhodlání nedopustit nečinnost, která by mohla mít dva základní neblahé dopady. Především šlo o to, že by se do této části Afriky mohly začít vměšovat ČLR a Ruská federace. A dále šlo o to, aby události v SAR nepodnítily zvýšenou aktivitu regionálních států, zejména pak DRC a také Čadu, který se snaží být př́itomen v celé střední Africe. [13]

Právě přítomnost Čadu představovala zvlášt' naléhavý problém. Velitelé jednotek z této země nabírali mnoho islamistů, kteří pak rabovali křest’anské kostely, zabíjeli a znásilňovali. V důsledku toho se mezi křest’anským obyvatelstvem SAR rozhořela silná nenávist vyjadřovaná zkratkovitým spojením: příslušník Séléky $=$ muslim $=$ člověk z Čadu = zabiják. [14]

Výše citované zjednodušené rčení pronásledovaných středoafrických křest’anů v plném rozsahu zcela ve shodě s teoretickým závěrem, který před dvaceti lety vyjádřil Samuel Huntington. Ten napsal, že v každém konfliktu na civilizačních zlomech se navzájem zabíjejí tzv. primární aktéři, za nimiž vždy stojí tzv. sekundární aktéři, kteří ty primární aktéry podněcují k násilí a k zabíjení, které jim pak otevírá cestu k prosazování jejich zájmů. [15] Konfesionální rozpolcenost šla dokonce tak daleko, že chvílemi paralyzovala i činnost dva a půl tisíce vojáků z mezinárodní mise MISCA: čadští vojáci ohran̆ovali středoafrické muslimy, zatímco vojáci z Konga zase brali pod ochranu tamní křest'any. [16]

V krajním př́ípadě by se situace mohla dostat až tak daleko, že by se začal prosazovat tzv. súdánský scénár. Mohlo by dojít i komu, že země by se rozdělila na dvě části. Jednu by tvořil převážně muslimský sever, zatímco druhou by tvořil křest'anský jih země. Na počátku roku 2013 to je scénář krajně pesimistický, ale ani zdaleka jej nelze zcela vyloučit, protože propast mezi muslimskou a nemuslimskou částí země se stále prohlubuje. [17] 


\section{Legitimnost a legálnost}

Po afghánské, a zejména pak po irácké zkušenosti (OIF 2003) je v dnešním světě velmi důležité to, zda použití ozbrojené síly splňuje požadavky na legálnost a legitimnost. [18] Výchozí teoretickou inspirací pro posuzování těchto dvou klíčových otázek jsou stati celosvětově uznávaného odborníka, jímž je bývalý ministr zahraničí Austrálie Gareth Evans. Ten uvádí, [19] že použití síly je legitimní v tom případě, že se potvrdí jeho důvody. Konkrétně to znamená, že se musí potvrdit, že země, organizace či událost, jež byly označeny za hrozbu pro mezinárodní mír a bezpečnost, skutečně představovaly vážnou a naléhavou hrozbu pro mezinárodní mír a bezpečnost. Tvrzení o hrozbě musí být podloženo jasnými důkazy.

A pokud jde o legálnost, základním kritériem jsou rezoluce Rady bezpečnosti OSN (RB OSN). První rezoluce označuje danou zemi, organizaci nebo událost za hrozbu pro mezinárodní mír a bezpečnost. A v návaznosti na to přichází druhá rezoluce, která dává zmocnění užít všech nezbytných prostředků, tedy včetně použití síly proti organizaci či státu, jež byly označeny za hrozbu pro mezinárodní mír a bezpečnost.

Pokud rezoluci dávající zmocnění užít všech nezbytných prostředků schválí všichni stálí členové RB OSN a žádný z nich ji nevetuje, pak se to považuje za mandát RB OSN k použití síly. Výslovně to znamená, že všechna následující opatření vojenského charakteru, při nichž mohou být nasazeny pozemní, vzdušné nebo námořní síly členských států OSN, jsou považována za legální. Jsou plně v souladu s mezinárodním právem a jejich smyslem je naplnit článek č. 42 kapitoly VI Charty OSN, kterým je obnovení mezinárodního míru a bezpečnosti v oblasti.

Z hlediska mezinárodního práva je zásadně důležité, že francouzská intervence je především zcela legitimní. Plně se potvrdily všechny důvody, žádný z nich nebyl zpochybněn. Plně se to odráží v rezoluci č. 2127 ze dne 5. 12. 2013, která je výjimečně rozsáhlá, má celkem 62 článků na 12 stranách. Její úvodní preambule zdůrazňuje, že dramatická situace představuje hrozbu pro mír a bezpečnost v SAR. Konkrétně zmiňuje především narůstající dynamiku vzájemného násilí a vyvražd'ování. Jako další hrozby pak uvádí nekontrolovatelnost situace, která vyúst’uje ve zločiny proti lidskosti.

Zároveň s tím francouzská intervence je od samého počátku také zcela legální. Klíčový význam má článek č. 50, který dává zmocnění užít všech nezbytných opatření (authorisation to use all necessary means).

Z hlediska nasazení vojenských jednotek v takovémto typu vnitrostátního ozbrojeného konfliktu s možným dopadem na sousední státy je zásadně důležitý článek č. 28, jenž stanovuje, že pod pojmem nezbytná opatření se rozumí následující souhrn činností:

- ochrana civilního obyvatelstva a obnovení bezpečnosti a veřejného pořádku,

- celková stabilizace země a obnovení autority státu na celém území SAR,

- vytvoření podmínek pro distribuci humanitární pomoci obyvatelstvu, které ji potřebuje,

- rozhodná podpora procesu odzbrojování, demobilizace, repatriace, reintegrace a znovu obydlování občanskou válkou postižené země (DDRRR),

- zajištění národního a mezinárodního úsilí při reformě a restrukturalizaci sektorů obrany a bezpečnosti.

Dále se zmocnění „přijímat všechna nezbytná opatřeni““ vztahuje i na zajišt'ování zbrojního embarga, zejména pak na postupy, které zabraňují přímému i nepřímému 
dovozu zbraní, munice vojenských automobilů či náhradních dílů do SAR. Stejně tak mají francouzští právo bránit př́sunu vojenských žoldáků z jakýchkoliv soukromých vojenských společností.

Klíčovou úlohu při koncipování rezoluce 2127 hráli právě francouzští politikové a diplomaté. [20] Tato rezoluce je skutečně takříkajíc šita na míru potřebám Francie, což má ale i svoji stinnou stránku: Francie je v SAR poněkud izolována, musí spoléhat především sama na sebe.

\section{Nasazení francouzských ozbrojených sil}

Sílící etnické násilí a narůstající počet obětí se staly velkou a naléhavou výzvou pro nejvyšší francouzské politické činitele. Prezident Francois Hollande jakožto vrchní velitel vyhlásil cíl zastavit vzájemné vyvražd’ování a nesmírné lidské utrpení. [21] V návaznosti na něho pak ministr zahraničí Laurent Fabius doplnil, že dalším úkolem je zajistit bezpečnost a vytvořit předpoklady pro obnovu a rekonstrukci této těžce zkoušené země. A konečně ministr obrany Yves le Drian dodal, že operace bude krátká, a proto také dostala název Sangaris, což je pojmenování tamního exotického motýla, který žije jen velice krátkou dobu.

Operace Sangaris: V noci na 6. prosince 2013 začala po jednomyslném schválení rezoluce 2127 Bezpečnostní rady OSN ve Středoafrické republice operace Sangaris. Vyhlášeným cílem operace bylo zajištění bezpečnosti a humanitární pomoci misi Africké unie v SAR (MISCA). Francouzský prezident zdůraznil, že intervence do SAR se provádí $\mathrm{z}$ humanitárních důvodů, a nikoli pro boj s terorismem.

Francouzské ozbrojené síly již na tento okamžik byly připraveny. Na vrcholové úrovni má př́pravu takovýchto rychlých zásahů na starosti Středisko doktrín pro použití ozbrojených sil (Centre de doctrine d' emploi des forces armées). Jeho činnost vychází především z neustálého doplňování a vyhodnocování informací o místech, ve kterých se hromadí krizové jevy, a která by se proto mohla stát dalším prostorem pro zasazení francouzských vojákủ. Nedílně $\mathrm{s}$ tím se $\mathrm{v}$ tomto středisku pečlivě a důkladně vyhodnocují zkušenosti z předcházejících operací. [22] Do popředí pozornosti se přitom dostávají zejména poznatky a zkušenosti z bojů v pouštním prostředí a před dokončením je dokument o př́ipravě na boj v tropickém prostředí.

Důležitou úlohu při shromažd’ování informací sehrávají speciální síly, především pak 13. vzdušně výsadkový pluk a 1. výsadkový pluk námořní pěchoty. Právě jejich př́slušníci byli doposud vždy nasazováni jako první ve všech operacích. Jejich úkolem bylo zjišt'ovat informace o postavení jednotek protivníka, navádět vlastní jednotky vzdušných i pozemních sil a ničit důležité nepřátelské objekty. Jimi dodané informace se pak shromažd’ují a využívají se při přípravě dalších operací.

Po získání mandátu RB OSN francouzské ozbrojené síly nejprve nasadily vzdušně výsadkový ženijní pluk, jehož vojáci zajistili kontrolu letiště Mpoko a v návaznosti nato připravili podmínky pro nástup dalších vojsk. Dalším jejím důležitým úkolem bylo zajistit ochranu francouzským státním příslušníkům pobývajícím na území SAR, což mimo jiné zahrnovalo také ostrahu Velvyslanectví Francouzské republiky v hlavním městě Bangui. 


\section{Zasazení víceúčelového vylod'ovacího plavidla Dixmude}

Významným nástrojem první fáze francouzské operace v SAR se stalo velitelské a vylod'ovací a velitelské plavidlo Dixmude. Jedná se o velkou pýchu celých francouzských ozbrojených sil, o nejmodernější vylod'ovací plavidlo třídy Mistral (L9015), které bylo dáno do operačního užívání na začátku roku 2013. Je sice součástí vojenského námořnictva, ale je také či spíše především novou platformou pro přepravu pozemního vojska při operacích v zámoří. Dixmude je jedním ze tří plavidel, která byla postavena tak, aby mohla plnit úkoly jak v rámci vzdušně-námořních složek francouzských ozbrojených sil, tak i v rámci aliančních sil rychlé reakce (NRF - NATO Response Force). Další jejich poslání se váže na mírové operace OSN, případně i na zásahy v rámci Evropské unie.

Z jejího názvu vyplývá, že plní dvě hlavní poslání - vylod'ovací a velitelské. Z hlediska první funkce je toto supermoderní víceúčelové vylod'ovací plavidlo (BIP - bâtiment d'intervention polyvalent) tak výkonné, že se mu často přezývá námořní airbus. Bylo postaveno pro potřeby francouzského vojenského námořnictva jako nosný nástroj doktrinální koncepce obojživelných operací (CNOA - Concept National des Operations Amphibies, du 10 juin 1997). Tato doktrína stanovuje celkem čtyři typy operací. Prvním z nich je vylodění intervenčních ozbrojených sil (amphibious assault, podle terminologie NATO), druhou možností je zpětné nalodění zasahujících vojsk (amphibious withdrawal), třetí je obojživelná operace (amphibious demonstrative) a konečně čtvrtou je rychlý zásah (amphibious raid). V prípadě intervence v SAR se od samého počátku klade důraz především na první a na druhý typ vojenské operace.

Ale ve srovnání se stejnými plavidly ostatních členských zemí NATO mají francouzská plavidla této kategorie jednu zásadní odlišnost - jsou dána do podř́zenosti pozemního vojska. Jsou určena k rychlé přepravě 9. lehké obrněné brigády, 6. lehké obrněné brigády. 4. vzdušně výsadkové brigády a 519. dopravního pluku, jehož hlavním úkolem je připravovat podmínky pro rozvinování vysazovaných jednotek.

Dixmude stejně jako ostatní dvě francouzská vylod'ovací a velitelská plavidla může přepravovat 450 vojáků i s jejich výzbrojí, včetně lehkých obrněných terénních vozidel Peugeot P4 či nejmodernějších tanků Nexter AMX-56 Leclerc, ale těch může přepravovat nanejvýš 13 , zatímco terénních vozů může pojmout až stovku.

Úderná síla plavidla Dixmude je dána především tím, že je platformou (nositelem) moderních bitevních vrtulníků. Proto se mu v atlantické terminologii říká Landing Helicopter Dock (LHD). Znamená to, že z ní mohou vzlétat a stejně tak na nich i prristávat bitevní vrtulníky. Proto na jeho služby spoléhají především pluky vojskového letectva. Oficiální název je Aviation legere de l'Armée de Terre, tj.lehké letectvo pozemního vojska, které sestává z celkem pěti vrtulníkových pluků, v jejichž výzbroji jsou moderní vrtulníky Puma, Gazelle a Tigre. Tyto pluky byly původně postaveny pro potřeby vedení bojové činnosti na evropském válčišti, ale po skončení studené války se zúčastnily operací v Afghánistánu i na různých místech v Africe, díky nimž mají bohaté zkušenosti. [23] Dnes představují jednu z velkých priorit francouzských ozbrojených sil [24] - především proto, že jsou nezastupitelným zbraňovým systémem pro potřeby mírových operací a intervencí v Africe, v Mali, s současné době v SAR. 
Pokud jde o druhou, tedy o velitelskou funkci, mají tato plavidla systém shromažd’ování a vyhodnocování informací, díky kterému mohou všechny aktivity vyloděných jednotek koordinovat v rámci režimu elektronicky řízené války (NCW - Network Centric Warfare), samožrejmě, že mají i systém rozlišování mezi vlastními a nepřátelskými vojsky (IFF - Friend or Foe).

V př́padě operace Sangaris byla plavidla Dixmude využita k přepravě nasazených vojáků a veškeré jejich bojové techniky z posádky Toulon na jihu Francie až do Guinejského zálivu. A odtud pak už vrtulníky létaly přes území Kamerunu až na místo určení v SAR. A toutéž cestou se přepravovala i vojska se svým zařízením. Při tomto přesunu se francouzští vojáci inspirovali i zkušenostmi amerických vojsk z Afghánistánu v roce 2001. Samozrrejmě, že operace Trvalá svoboda (OIF) byla mnohem rozsáhlejší a náročnější, ale podstata byla stejná: využití vojenských plavidel pro přepravu jednotek pozemního vojska a jejich bojové techniky do vnitrozemského státu.

\section{Francouzské výhrady proti operaci v SAR}

Samozřejmě, že zaznívají i výhrady. První je spíše technického charakteru a zpochybňuje přesvědčení nejvyšších politických činitelů Francie, kteří tvrdili, že operace bude velmi krátká, nejdéle šest měsíců. Mnozí očekávají, že budou vyvstávat stále nové a nové problémy, a tak mise bude delší, podobně jako v př́padě pobytu amerických vojáků v Afghánistánu nebo v Iráku.

Ale druhá výhrada je vážnější. Varuje, že během posledního půl století to je už celkem padesátá vojenská intervence $v$ Africe, přičemž většina $z$ nich měla pro samotnou Francii neblahé důsledky. Např. profesor Michel Galy připomíná, že jeho země nejednou podpořila diktatury, jindy zase uměle vytvářela tzv. demokratury, které ale stejně neměly dlouhého trvání. Jiní dokonce hovoří o neokolonialismu, který může mít zpětné destabilizující dopady na samotnou Francii. [25]

\section{Význam středoafrické operace pro Českou republiku}

Pokud jde o naši zemi, francouzská intervence nepředstavuje událost prvořadého významu. MZV ČR ve svém prohlášení ze dne 20. 1. 2014 ocenilo, že tato operace probíhá v rámci tzv. společné bezpečností a obranné politiky (CSDP) a že jejím úkolem bude obnova bezpečnosti v zemi a podpora africké mise AFISM-CAR (MISCA). Zdůraznilo, že Česká republika tuto operaci podporuje, ale neplánuje do ní vyslat vlastní vojenské jednotky. [26]

Zdrženlivost je skutečně namístě, a to tím spíše, že v samotné Francii je tato operace hodnocena jako velký paradox spočívající v tom, že stát, který před půl stoletím nabyl samostatnost, se najednou stává závislý na tom, zda mu pomůže bývalá koloniální velmoc. Něco takového se tedy může přihodit pouze koloniálním státům, ale nehrozí to státům typu České republiky. My sami žádné bývalé impérium ani sféru vlivu v Africe nemáme, a tak ani nebudeme čelit výzvám a problémům tohoto typu. 
Ale i pro nás je operace Sangaris velice zajímavou událostí a námětem zasluhujícím důkladné a pozorné sledování, a to hned z několika důvodů. Především je a ještě bude důležité sledovat, jak si povede jedna ze tří klíčových zemí EU při snaze o stabilizaci významné části nejproblematičtějšího kontinentu dnešního světa, při řešení krizí, které přinášejí velké lidské utrpení a které vždy představují hrozbu širší mezinárodní destabilizace.

Druhým důvodem je finanční stránka každé takovéto operace. Již první poznatky ukazují, že jen jeden let Paříže do Bangui a zpět s pronajatými letouny Antonov stojí až půl milionu euro a takových letů se musí udělat několik desítek. V tomto směru Francii do značné míry zachránilo, že pronájem dopravních letounů hradila EU.

A konečně třetím důvodem jsou nároky na přípravu a zabezpečení vojáků nasazovaných v Africe. Tyto nároky se dělí do dvou skupin: logistické, bojové a duševní. První skupina zahrnuje takové nároky, jakými jsou vhodná výstroj, zabezpečení 10 litrů vody na jednoho vojáka a jeden den, zajištění stravy uzpůsobené potřebám afrického válčiště. Bojové nároky zahrnují sportovní a taktický výcvik před nasazením vojáků do Afriky, jejich př́pravu na velice drsné klimatické podmínky. To vše jsou věci, jejichž zajištění ještě před misí nepředstavuje velké problémy.

Ale operace Sangaris ukazuje, že jsou i úkoly, které vyžadují zvláště náročnou př́ípravu. Je to především urovnávání sporů mezi etnickými nebo dokonce náboženskými skupinami, které se navzájem nenávidí na život a na smrt.. V konkrétním př́padě SAR to bylo například zvažování řady dilematických otázek. První z nich zněla, jak přistupovat k provládním silám, o kterých se dobře vědělo, že samy spáchaly řadu těžkých zločinů. A zároveň s tím šlo i o to, jak postupovat při zatlačování islamistických milicí zpět do kasáren, aniž by přitom došlo k tomu, že nemuslimské obyvatelstvo pak rozpoutá pomstychtivé akce proti muslimům.

Byly to velmi těžké otázky, které se ale mohou kdykoliv opakovat i v další africké zemi. Také to jasně napovídá, že zásahy v takovýchto zemích by měly být prioritně záležitostí bývalých koloniální zemí, které tamní poměry dobře znají a mají dlouhodobé zkušenosti. Naproti tomu pro zemi jako je ČR z toho vyplývá požadavek na maximální zdrženlivost a obezřetnost.

\section{Psychologické aspekty misí v Africe}

Zvláštní pozornost si zasluhují nároky duševního charakteru. Ty se rozdělují do dvou etap. První etapa zahrnuje přípravu na misi, kde jde především o přípravu na zátěžové situace. Druhá etapa se soustřed’uje na dobu po návratu z bojového nasazení a zahrnuje dlouhou léčbu posttraumatických syndromů. Nejčerstvější francouzská zkušenost je taková, že psychologickou léčbu potřebovalo 48 z 80, tedy plných 60 \% vojáků, kteří se vrátili z bojového nasazení v africkém Mali.

Vyhodnocováním traumatických prožitků z misí se zabývá lékařské a psychologické středisko francouzských ozbrojených sil. Jeho šéf Patrick Devillieres zdůrazňuje, [27] že hlavními startéry traumat vojáků nasazovaných v Africe jsou odhodlání džihádistických sebevrahů, zkušenosti z bojů zblízka a ve stále větším rozsahu také využívání dětských vojáků, kteří jsou v Africe nasazováni stále častěji. Podle zprávy UNHCR v současné době ve Středoafrické republice bojuje šest tisíc dětských vojáků. Právě 
to je věc, která vojákům ze západní civilizace, a zejména pak z Evropy, činí největší psychologické potíže. Jsou šokováni z toho, kdo proti nim stojí, a nejsou připraveni na to, aby dětské vojáky zabíjeli. Výsledkem pak jsou traumata, kterým podléhají i ti nejlépe připravovaní vojáci. Projevují se především pocity osamělosti, poruchami spánku, stavy úzkosti, uzavřeností.

Výše zmiňovaná traumata a jejich následné překonávání se týkají především těch států, které dodávají velké bojové jednotky. Ale nejsou bez zajímavosti ani pro Českou republiku, už jenom z toho důvodu, že poslala několik svých vojáků do Mali. Nebyli sice nasazeni do první linie bojů, ale i oni byli vystaveni vlivu mnoha nepř́znivých faktorů. Z toho lze vyvozovat, že i pro naše vojáky bude př́nosné zabývat se francouzskými zkušenostmi z Mali, jakož i ze SAR.

\section{Závěry}

Francouzská operace Sangaris 2013 ukázala, v čem spočívají bezpečnostní výzvy spojené se soudobou centrální Afrikou. Jsou to nahromaděné problémy, především náboženská nesnášenlivost, chudoba, politická nestabilita, sklony tamních vưdců k násilným převratům a $\mathrm{k}$ diktátorskému vládnutí. Vyhrocená náboženská nesnášenlivost a vzájemné vyvražd'ování v SAR potvrzují náležitost a vysokou hodnotu jeho doporučení, že př́ípadné intervence západní civilizace $\mathrm{v}$ jiných civilizačních okruzích by se měly uskutečňovat na základě společného zprostředkování a všeobecně přijatelných hodnot. V prrípadě operace Sangaris se zasahovalo v rámci mezinárodního společenství a na základě ústřední společné hodnoty, kterou je zastavení vzájemného vyvražd'ování a obnovení základních funkcí státu.

Další z velkých výzev spočívá v tom, aby řešení takovýchto krizí nebylo jen záležitostí jedné země, bývalé koloniální mocnosti. Země tohoto typu, jmenovitě Francie a Velká Británie, jistě mají největší povinnosti, už proto, že dobře znají terén a hlavně mentalitu tamního obyvatelstva. Ale i tak vyhrocená krize v SAR ukázala na nezbytnost vypracovat společnou politiku EU v př́stupu k Africe. [28] Taková politika by mohla a měla zahrnovat nejprve preventivní působení a v př́padě dalších humanitárních krizí i možné společné intervence, na nichž by se mohly podílet i další silné státy EU, zejména pak SRN. [29] Vyjádření nejvyšší představitelky EU pro zahraniční a bezpečnostní politiku ukázala, že na nejvyšší obecné úrovni existuje vstřícnost, [30] ale dotažení do roviny konkrétních společných př́stupů a postupů je úkolem pro budoucnost.

V neposlední řadě operace Sangaris znovu připomněla psychologickou náročnost jakéhokoliv nasazení vojenských jednotek v Africe. Z tohoto hlediska by měli být nejlépe připraveni vojáci z někdejších koloniálních zemí, ale je to výzva i pro armády dalších členských států EU. Jejich př́islušníci totiž mohou být nasazováni třeba ,jen“ jako instruktoři nebo zdravotníci. Zvěrstva, se kterými se tam budou setkávat, pro ně budou velmi otřesným, až traumatizujícím zážitkem. O to náročnější je příprava před misí, kde by velkým zdrojem poznatků mohly být zkušenosti specializovaných pracovišt' ve Francii, Velké Británii a samozrejmě také v USA.

V podobných spojeneckých akcích, na jedné ze stran toho či onoho sporu, který vyúst’uje v ozbrojený konflikt, se ocitneme častěji. Vyplývá to z členství v NATO. Naše spojenecké závazky jsou srozumitelné a nepochybné. Česká republika by ale měla být 
opatrná, protože v etnicko-náboženských konfliktech tohoto typu na ni čeká celá řada velmi nebezpečných úskalí. První z nich je dáno tím, že my Češi nemáme náležité znalosti např. o regionu střední Afriky. Nemáme odpovídající zkušenosti s tamním terénem, klimatem, a hlavně s mentalitou tamního obyvatelstva. Ve všech těchto směrech výrazně zaostáváme za Francouzi, kteří tuto oblast znají mnohem déle a především mnohem důvěrněji.

Druhé úskalí je dáno tím, že naši vojáci by se mohli dostávat do situací, za kterých na ně může jedno nebo i obě znesvářená bojující uskupení tlačit, aby se přidali právě na jejich stranu. Ale v takovém prrípadě by především porušili základní zásadu mírových operací, kterou je nestrannost. A navíc by se rychle stali rukojmím té strany, na kterou by se přiklonili. Obě skutečnosti by mohly mít doslova fatální dopady. Třetí úskalí představuje výše vzpomínaný súdánský scénář, tedy př́ípadné rozdělení země na konfesionálním základě. Také od takto výbušné otázky by si ČR měla držet náležitý odstup. Její aktivní úloha by se měla řídit zkušeností z Mali: měla by se omezit nanejvýš na instruktory, na tzv. mentorskou činnost.

\section{Použitá literatura:}

[1] Více k těmto operacím, viz KOLLER, Martin, Malá válka s možnými velkými dopady. Vojenské rozhledy, 2013, roč. 22 (54), č. 2, s. 150-167, ISSN 2010-3292, internetová verze ISSN 2336-2995; EICHLER, Jan, Operace Serval 2013: Nasazení francouzské armády v Mali, Vojenské rozhledy, 2013, roč. 22 (54), č. 2, s. 133-149, ISSN 2010-3292, internetová verze ISSN 2336-2995.

[2] SAINT VICTOR de, Florent. 45 ans d'opérations militaires francaises en République Centrafricaine. Lettre du retex - Opérations. N. 8. Paris: Centre de doctrine d'emploi des forces, 2013.

[3] CHAUPRADE, Aymeric; Thual, François, Dictionnaire de géopolitique. états, concepts, auteur, 1. ed. Paris. Ellipses, 1998.

[4] TELIČKA, Marek, Středoafrická republika: Převraty a bída. 100+1, 18. 4. 2013, dostupné na http:// www.stoplusjednicka.cz/stredoafricka-republika-prevraty-bida.

[5] AMSELLE, Jean-Loup. Un continent frappé par l' effondrement de l'Etat. Le Monde, 6.12. 2013.

[6] GUIBERT, Nathalie. Les coulisses des guerres au Mali et en Centrafrique. Le Monde, 8-9. 12. 2013.

[7] JAULEMS, Adrien. A Bangui, les débuts positifs de l' opération Sangaris. Le Figaro, 6.12. 2013

[8] CHATELOT, Christophe. Centrafrique: pourquoi intervenir. Le Monde, 19. 12. 2014.

[9] Le Monde, 27. 12. 2013.

[10] Que va faire l' armée francaise en République centrafricaine? Le Mode. 28. 11. 2013.

[11] OURDAN, Rémy. Les trois saints de Bamgui. Le Monde, 28.12. 2013.

[12] NZAPALAINGA, Dieudonné et LAYAMA, Omar Kobine. Centrafrique: Le pire pourrait etre encore a venir. Le Monde, 27.12. 2013.

[13] De VILLEPIN, D. Paris ne doit pas agir seul, mais mobliser le Conseil de sécurité et l'Europe. Le Monde, 6.12. 2013.

[14] BENSIMONY, Cyril. Centrafrique. le risque d' un conflict confessionnale. Le Monde 22-23. 12. 2013.

[15] HUNTINGTON, Samuel P. Střet civilizací: boj kultur a proměna světového řádu. Praha: Rybka, 2001.

[16] OURDAN, Rémy. En Centrafrique, les forces musulmanes de l' ex-Séléca s'en prennet a la France. Le Monde, 24.12. 2013.

[17] OURDAN, Rémy. En Centraafrique, les forces musulmanes de l' ex Séléka s' en prennent a la France. Le Monde, 24.12. 2013.

[18] Rozdíl mezi legitimitou a legalitou, více viz EICHLER, Jan. Legální a nelegální války v dnešním světě. Vojenské rozhledy, 2012, roč. 21 (53), č. 3, s. 17-29, ISSN 2010-3292, internetová verze ISSN 2336-2995.

[19] EVANS, Gareth. When is it Right to Fight?, Survival, Volume 46, Number 3, 2004.

[20] HEISBOURG, Francois. Mobilisons l'Europe pour la RCA! Le peché originel d'une France trop isolée. Le Monde, 27.12. 2013. 
[21] Francois Hollande a Bangui. Le Monde, 12. 12. 2013.

[22] VENNESSON, Pascal. Penser les guerres nouvel les: La doctrine mil itaire en questions, 18 déc. 2013, Centre de doctrine d'emploi des forces.

[23] MARTINI, André. L'histoire de l'aviation légère de l'armée de terre 1794 - 2004: De l'Entreprenant au Tigre. Éditions Lavauzelle, 2005.

[24] Rapport du Sénat français de 2002; Les hélicoptères de l'armée de Terre: situation et perspectives.

[25] AMSELLE, Jean-Loup. Un continent frappé par l' effondrement de l'Etat. Le Monde, 6.1 2. 2013.

[26] Prohlášení MZV ke zvolení prozatímní prezidentky Stredoafrické republiky. Dostupné na http:// www.mzv.cz/jnp/cz/udalosti_a_media/prohlaseni_a_stanoviska/x2014_01_22_prohlaseni_ke_ zvoleni_prozatimni_prezidentky_stredoafricke_republiky.html.

[27] DEVILLIERES, Patrick. Soigner les blessures invisibles - Ministère de la Défense. Dostupné na www. defense.gouv.fr/actualites/articles/soigner-les-blessures-invisibles\$30 janv. 2013.

[28] FRANCE de, Olivier. L'Europe doit se doter d' une stratégie globale de défense et de sécurité. Le Monde, 18. 12. 2013.

[29] LEQUESNE, Christian. Le couple franco-allemand reste le moteur de l' Europe. Le Monde, 31. 12. 2013.

[30] ASHTON, Catherine. Mutualisons notre défense européenne pour protéger nos valeurs. Le Monde, 20. 12. 2013.

Některé zkratky užité v textu:

\begin{tabular}{|c|c|c|}
\hline $\mathbf{A U}$ & African Union & $\begin{array}{l}\text { Africké unie (nástupce Organizace } \\
\text { africké jednoty) }\end{array}$ \\
\hline BIP & bâtiment d'intervention polyvalent & víceúčelové vylod’ovací plavidlo \\
\hline CAR & Central African Republic & Středoafrická republika, SAR \\
\hline CNOA & $\begin{array}{l}\text { Concept National des Operations } \\
\text { Amphibies }\end{array}$ & $\begin{array}{l}\text { koncepce národních obojživelných } \\
\text { operací }\end{array}$ \\
\hline CSDP & Common Security and Defence Policy & $\begin{array}{l}\text { společná bezpečnostní a obranná politika } \\
\text { EU (která je součástí společné zahraniční } \\
\text { a bezpečnostní politiky, CFSP) }\end{array}$ \\
\hline DRC & Democratic Republic of the Congo & Demokratická republika Kongo \\
\hline DDRRR & $\begin{array}{l}\text { Disarmament, Demobilization, } \\
\text { Repatriation, Reintegration and } \\
\text { Resettlement of foreign armed groups }\end{array}$ & $\begin{array}{l}\text { obydlování občanskou válkou postižené } \\
\text { země }\end{array}$ \\
\hline IDP & Internally Displaced People & běženci, vyhnanci \\
\hline IFF & identification Friend or Foe & $\begin{array}{l}\text { identifikace vlastní - cizí, } \\
\text { obvykle vyslovováno [aj ef ef] }\end{array}$ \\
\hline LHD & Landing Helicopter Dock & letiště pro helikoptéry, heliport \\
\hline MISCA & $\begin{array}{l}\text { Mission internationale de soutien } \\
\text { à la Centrafrique sous conduite } \\
\text { africaine } \\
\text { (AFISM-CAR - The African-led } \\
\text { International Support Mission } \\
\text { to the Central African Republic) }\end{array}$ & $\begin{array}{l}\text { Mezinárodní mise na podporu } \\
\text { Středoafrické republiky }\end{array}$ \\
\hline NCW & Network Centric Warfare & $\begin{array}{l}\text { vedení bojové činnosti s využitím } \\
\text { centrálních sítí }\end{array}$ \\
\hline NRF & NATO Response Force & síly reakce NATO \\
\hline OEF & Operation Enduring Freedom & operace Trvalá svoboda (v Afgánistánu) \\
\hline OIF & Operation Iraqi Freedom & operace Irácká svoboda \\
\hline UNHCR & $\begin{array}{l}\text { Office of the United Nations High } \\
\text { Commissioner for Refugees }\end{array}$ & Vysoký komisariát OSN pro uprchlíky \\
\hline
\end{tabular}

